\title{
COCOA FARMER CHARACTERISTICS AND ACCESS TO RESEARCH- BASED INFORMATION IN TWO DISTRICTS OF ASHANTI, GHANA
}

\author{
F. Baah \\ Cocoa Research Institute of Ghana, Tafo-Akim, Ghana
}

\begin{abstract}
The main purpose is to review the state of cocoa extension system and its preparedness to meet the information needs of resource-poor farmers. It also sought to investigate the extent of farmer access to research-based information and how this access is influenced by certain farmer characteristics. Social survey involving questionnaire administration and statistical analyses were employed. Information was elicited from 278 farmers in ten communities in two political districts (Atwima Mponua and Amansie West) of Ashanti, Ghana. Contrary to recent review reports, this study found that $83.8 \%$ of farmers have not met an extension agent in the year preceding the study. Farmers relied heavily on their network of family members and friends for information on cocoa and only $13 \%$ regarded the extension system as reliable information source. The farmers preferred to receive information through the radio which almost all had. Of the farmer characteristics examined, only district of residence and class of farmer showed significant relationship with access to research-based information. The implications are that farmer access to research-based information is low such that the characteristics of the farmer are largely immaterial. The findings have implications for government policy on extension support systems to cocoa farmers. It suggests that the policy of merging cocoa extension with mainstream ministry of agriculture extension may be flawed because it was meant to improve farmers' access to information and as the findings of this study indicates, not much has been achieved in that direction. The study has practical value for policy formulation and the choice of appropriate media for interacting with farmers.
\end{abstract}

Keywords: Information, access, characteristics, cocoa

\section{INTRODUCTION}

Ghana as a country is almost synonymous with the cocoa crop. Since its introduction from Fernando Po in 1879, cocoa has transformed the nature of agricultural activities and has occupied centre stage in the country's socio-economic development. Besides revenue to the state, cocoa cultivation supports the livelihoods of over 600,000 farmers and their dependants working on over 1.2 million hectares of land (MASDAR,

10 Journal of Science and Technology, Vol. 28, No. 3, Dec., 2008 
1998). Whereas the country has recovered from the decline in cocoa production in the 1980s, productivity on farmers' farms remain low relative to Ghana's competitors (average yields are $300 \mathrm{~kg} / \mathrm{ha}, 600 \mathrm{~kg} / \mathrm{ha}$ and $800 \mathrm{~kg} / \mathrm{ha}$ respectively for Ghana, Cote d'Ivoire and Brazil) (ICCO, 2007). Information provision and extension support to farmers are central to the efforts to raise output per unit area. Information and access to it are increasingly being regarded as important resources especially in third world agriculture. Access to information is more crucial and lack of it more critical in agriculture than in other areas of human endeavour because the agricultural sector is relatively more volatile and subject to vicissitudes of the weather, prices and markets (ISNAR, 1991; Röling and Engel, 1991). The main use of information is to reduce uncertainty about innovations or new ideas and assist in decision-making and problem-solving processes (Barnard, 1979; Rogers, 1995). But is access to information per se enough to solve the numerous problems facing third world agriculture? Myren (1964) suggested that adequate information alone would not eliminate the uncertainty which makes it undesirable for the farmer to go ahead with a new practice. Such information would need to include both knowledge of the relationship between present factors and adequate knowledge about future and new factors. Hornik (1988) was of the view that the position that information provision alone can resolve development problems assumes that available resources are being effectively used. What needs to be said according to him is that substantially more benefit can be derived from what is already in place, if only individuals or perhaps groups knew better how to organise the use of those resources.

Information alone is certainly not enough to produce the changes that are so desired in the development context of third world without adequate supplies of needed inputs and enabling institutional environments. Many extension workers are frustrated by the difficulties of trying to induce changes in farmers with new information without the input support to enable them to put it into practice. We can conclude that access to information is certainly a necessary, though not a sufficient, condition for a change in farmers' behaviour and farming practices. Since access to information is critical in the quest to raise farmers' productivity, the objective of this study is to evaluate the extent to which cocoa farmers have access to research-based (information from the formal research institutes, specifically the Cocoa Research Institute) and how this access is influenced by farmer characteristics. Thus, it was hypothesised that there is a relationship between farmer characteristics (age, sex, participation in farmer field schools, class of farmer, category of farmer, district of residence, and membership of farmer organisation) and access to researchbased information. It is recognised that farmers do obtain information from non-formal sources but these were deliberately left out to allow for the evaluation of the formal system which has a mandate to produce and make available farmerrelevant research-based information to support cocoa production.

\section{Conceptual framework}

A conceptual framework has been described as a formal way of thinking (i.e. conceptualising) about a process or system under study (Smyth, 2004). In this study, farmer characteristics are the independent variables in relation to the dependent variable, access to research-based information, which in this study was measured by the frequency of contact with extension agents. This proxy was used because it was realised during interactions with key informants prior to the survey that access to research-based information was low such that to measure differentiation of access, frequency of contact was more useful than mere contact. The meaning of the independent variables and their categories are given in Table 1. An overview of the conceptual framework is provided in Figure 1.

The absence of arrows on the lines linking the independent variable, access to research-based information and the dependent variables is in- 


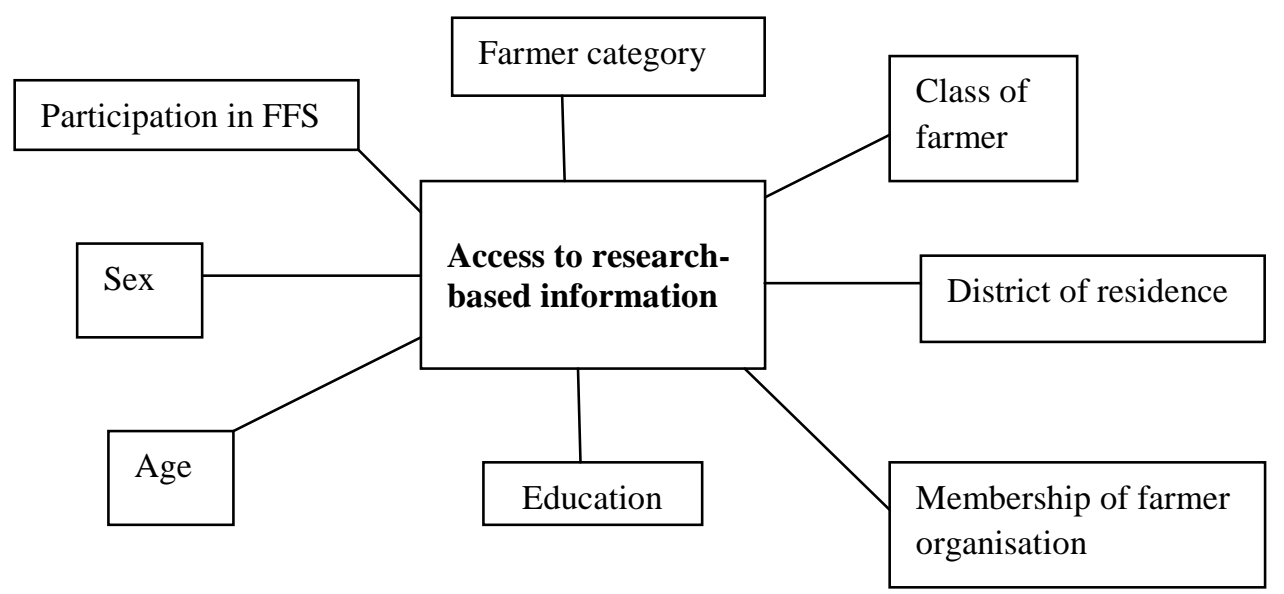

Fig. 1: An overview of the conceptual framework

dicative of the fact that the study recognises that the relationship could go the other way (this is in respect of the variables participation in FFS, Farmer category, Class of farmer, Education and Membership of farmer organisation) though these were not explored. It is also recognised that there could be interrelationships between some of the independent variables (educational attainment and class and category of farmer, and membership of farmer organisation for instance) but these were not explored in this study. For instance, Bembridge (1993) showed that there is positive correlation between farmers' educational attainment and membership of farmerbased organisations, and Asante (1998) also showed that educational attainment also influences class and category of cocoa farmers as well as membership of farmer organisation.

\section{METHODOLOGY AND METHODS}

The study's methodology is survey research, defined as an investigation where systematic measurements are made over a series of cases yielding a rectangle of data; the variables in the matrix are analysed to see if they show any patterns and the subject matter is social (Marsh, 1982). The methods employed are questionnaire survey and statistical analyses using the Statisti- cal Products and Service Solutions (SPSS version 13). Ashanti Region was selected purposively and the two districts, Amansie West and Atwima Mponua selected randomly by writing on pieces of paper the names of all the districts and mixing in a bowl, and picking one without replacement. Within the district, the list of the operational communities of the Produce Buying Company ( $\mathrm{PBC}$ - this is the leading cocoa buying company with presence in all the communities and has shown in the past to have reliable records of farmers and their communities) was used as a sampling frame. Five communities were selected randomly in each district. They are Akorabourkrom, Otaakrom, Kyereyaaso, Amadaa and Anweafutu in Atwima Mponua district; Esaaso, Aboabotetekaso, Tetrem, Kobeng and Ahwerewa in Amansie West district. The sample size of farmers to be interviewed was determined using methods suggested by Casley and Kumar (1988). A sample of 300 farmers across the ten communities was selected using systematic sampling procedures from list of farmers in the communities provided by the PBC with enumerators being able to interview 278 farmers using standardised questionnaires. The study was carried out between October 2007 and February 2008.

12 Journal of Science and Technology, Vol. 28, No. 3, Dec., 2008 
Table 1: Independent variables

\begin{tabular}{|c|c|c|}
\hline Variable & Meaning & Categories \\
\hline Sex & $\begin{array}{l}\text { Refers to whether a respondent was male or } \\
\text { female }\end{array}$ & $\begin{array}{l}\text { Male } \\
\text { Female }\end{array}$ \\
\hline Age & $\begin{array}{l}\text { This refers to the age of the respondent and } \\
\text { recorded in years }\end{array}$ & $\begin{array}{l}20-29 \\
30-39 \\
40-49 \\
50-59 \\
60 \text { and above }\end{array}$ \\
\hline Education & Level of education attained & $\begin{array}{l}\text { None } \\
\text { Primary } \\
\text { Junior secondary/ } \\
\text { vocational } \\
\text { Senior secondary/ } \\
\text { commercial } \\
\text { College/university }\end{array}$ \\
\hline District of residence & District where respondent lives & $\begin{array}{l}\text { Atwima Mponua } \\
\text { Amansie West }\end{array}$ \\
\hline Farmer category & $\begin{array}{l}\text { Cocoa farmer was classified on the basis of } \\
\text { the relationship between him/her and the land }\end{array}$ & $\begin{array}{l}\text { Owner-operator } \\
\text { Abunu } u^{1} \text { tenant } \\
\text { Abusa } a^{2} \text { tenant }\end{array}$ \\
\hline Class of farmer & $\begin{array}{l}\text { Cocoa farmers classified on the basis of the } \\
\text { use he/she make of research recommendations } \\
\text { into three categories (FAO/ World Bank, } \\
\text { 1986) }\end{array}$ & $\begin{array}{l}\text { High class } \\
\text { Medium class } \\
\text { Low class }\end{array}$ \\
\hline $\begin{array}{l}\text { Membership of farmer or- } \\
\text { ganisation }\end{array}$ & $\begin{array}{l}\text { This variable simply refers to whether a } \\
\text { farmer is a member of a farmer organisation } \\
\text { or not }\end{array}$ & $\begin{array}{l}\text { Yes } \\
\text { No }\end{array}$ \\
\hline $\begin{array}{l}\text { Participation in farmer field } \\
\text { school }\end{array}$ & $\begin{array}{l}\text { This simply ascertain if a farmer attends or } \\
\text { has been a participant in a farmer field school }\end{array}$ & $\begin{array}{l}\text { Yes } \\
\text { No }\end{array}$ \\
\hline
\end{tabular}

${ }^{I}$ An abunu tenant is a farmer who obtains a piece of land from a landlord and develops it into cocoa which when of age is shared (the land with the cocoa) one-half each between the tenant and landlord

${ }^{2}$ An abusa farmer is a tenant who manages someone's already established cocoa farm for a third of the produce only

\section{RESULTS AND DISCUSSION}

\section{Sample characteristics}

Ghanaian cocoa farmers like farmers elsewhere are not a homogenous group; they differ on many count such as age, sex, marital status class and category of farm, farm size and yield as presented in Table 2. Over half the sample (55.4\%) belongs to age band 50 years or over. Indeed the modal age was 60 years and above. This finding is consistent with findings of other studies (COCOBOD, 1995; Boahene, Snijders and Folmer, 1999; Baah, 2006; Asante, 1998) that the population of cocoa farmers is an ageing one. Over $79 \%$ of the sample consisted of married persons. Cocoa farmers traditionally have many children to provide the much needed labour and marriage is a natural step towards this.

More than half the sample $(76.2 \%)$ had received basic education (primary and secondary), $0.8 \%$ higher education (senior secondary and college) and $23 \%$ had no formal education. Since level of education has been shown to have a positive correlation with literacy level, readership of publications and newspapers (Bembridge, 1993), 
this sample may be said to be much more literate than is usually reported of cocoa farmers in Ghana. For instance, $47 \%, 55 \%$ and $71 \%$ of the farmers interviewed by Asante (1998), Donkor et al. (1991) and Arhin (1985) respectively had no formal education. Many researchers cite the reported illiteracy of farmers as a factor in the low adoption of research recommendations (Opare, 1977; Donkor et al., 1991; Boahene et al., 1999; Boahene, 1995).

Table 2: Sample characteristics

\begin{tabular}{|c|c|c|}
\hline Variable & Categories & \% Of Respondents \\
\hline \multirow[t]{5}{*}{ Age } & $20-29$ & 2.9 \\
\hline & $30-39$ & 13.1 \\
\hline & $40-49$ & 28.0 \\
\hline & $50-59$ & 27.6 \\
\hline & 60 and above & 28.4 \\
\hline \multirow[t]{2}{*}{ Sex } & Male & 59.7 \\
\hline & Female & 40.3 \\
\hline \multirow{4}{*}{$\begin{array}{l}\text { Marital } \\
\text { status }\end{array}$} & Married & 79.5 \\
\hline & Single & 3.6 \\
\hline & Divorced & 8.3 \\
\hline & Widowed & 8.3 \\
\hline \multirow[t]{5}{*}{ Education } & None & 23.0 \\
\hline & Primary & 41.0 \\
\hline & Secondary & 28.0 \\
\hline & College / & \\
\hline & University & 0.8 \\
\hline
\end{tabular}

Source: Survey data

Cocoa farmers traditionally have many children to provide the much needed labour for farm operations. The mean number of children was 9.51 ; the median was 6.00 and the range, 0-25. Cocoa farming is labour intensive and the low incomes of most farmers mean that they cannot afford to hire labour hence the reliance on family labour. Abenyaga and Gockowski (2001) estimate that for a farmer producing $940 \mathrm{~kg}$ in a year, the total annual labour demand for the major tasks associated with cocoa production is 178 person days (a person day is defined as six hours at the work site).

\section{Information sources}

Farmers were asked about their main and preferred sources of information and advice on co- coa. The responses are presented in Table 3. For an overwhelming majority of farmers, their fellow farmers, family members and other persons in their social networks are their main source of information and advice. But given the option to choose their information source, they prefer the radio which $66.2 \%$ of them own.

\section{Hypotheses testing}

Correlation analyses were employed to establish the validity of the hypotheses that the independent variables (education, gender, participation in FFS, farmer category, district of residence, and class of farmer) are related to the dependent variable, access to research-based information (see Figure 1).

Table 3: Farmers' main and preferred information sources

\begin{tabular}{lc}
\hline \multicolumn{1}{c}{ Source } & Percent Reporting \\
\hline Main information & \\
Other farmers / family & 10.1 \\
Extension agents & 13.3 \\
Licensed buying agents & 7.2 \\
Input dealers & 1.4 \\
Preferred information & \\
Radio & 62.6 \\
Licensed buying agents & 11.2 \\
Television & 13.3 \\
Researchers & 5.8 \\
Family/neighbours & 5.8 \\
Newspapers & 0.4 \\
\hline
\end{tabular}

Source: Survey data. Note that percentages may not add up to 100 because of non-response

The choice of correlation coefficient is influence by the nature of the variable and the number of categories (de Vaus, 2002). The results are presented in Table 4.

The relationship between farmers' level of education and frequency of contact with extension agents was examined. On the basis of correlation, the hypothesis that there is a relationship between farmers' educational attainment and access to research-based information is rejected (Table 4). Farmer educational level has often been associated with adoption of research rec-

14 Journal of Science and Technology, Vol. 28, No. 3, Dec., 2008 
ommendations (Matthews-Njoku, 2003; Matthews-Njoku and Asiabaka, 2003). Educated farmers adopt more and extension officers are attracted to them and therefore there is more contact between the two. The findings from this study do not support this assertion.

Similarly, the hypotheses that there is a relationship between the variables gender, participation in FFS, and farmer category and the dependent variable access to research-based information are rejected (Table 4).

This study found highly significant $(\mathrm{P}<0.01)$ differences between the classes of cocoa farmers and the frequency with which they meet or contact extension agents (Goodman and Kruskal's tau $-0.059, \mathrm{P}=0.004)$. On the basis of this, the hypothesis that there is a relationship between class of farmer and farmer access to researchbased information is accepted. This finding sup- ports the assertion by some researchers (Tripp et al., 2004) that better placed or resourced farmers (and high class cocoa farmers are better resourced than low class ones) are served better by extension than their poorer counterparts. In this study, $11.8 \%, 10.7 \%$ and $5.3 \%$ of high, medium and low class cocoa farmers respectively received extension support at least once per month.

No significant differences $(\mathrm{P}<0.05)$ were found between cocoa farmers in the two districts with respect to main information source (Cramer's V $=0.144, \mathrm{P}=0.319)$. However, farmers in the two districts differed significantly $(\mathrm{P}<0.01)$ in their preferred information source (Cramer's $\mathrm{V}=$ $0.228, \mathrm{P}=0.001)$. Similarly, highly significant differences $(\mathrm{P}<0.01)$ were observed between farmers in the two districts and their access to research-based information (Table 5). Consequently, the hypothesis that there is a relation-

Table 4: Correlation between access to research-based information and independent variables

\begin{tabular}{llcl}
\hline Variable & Correlation coefficient & Value & Significance \\
\hline Education & Goodman and Kruskal's tau & 0.017 & $0.528 \mathrm{NS}$ \\
Gender & Goodman and Kruskal's tau & 0.005 & $0.758 \mathrm{NS}$ \\
Participation in FFS & Cramer's V & 0.146 & $0.160 \mathrm{NS}$ \\
Farmer category & Goodman and Kruskal's tau & 0.013 & $0.079 \mathrm{NS}$ \\
District of residence & Cramer's V & 0.260 & $0.003 *$ \\
Class of farmer & Cramer's V & 0.059 & $0.004^{*}$ \\
\hline
\end{tabular}

Source: Survey data. $*$ Significant at $0.01 \%, N S=$ Not significant

Table 5: Frequency of contact with extension agents by district of residence

\begin{tabular}{lcc}
\hline \multirow{2}{*}{ Frequency of Contact } & \multicolumn{2}{c}{ District of Residence } \\
& $\begin{array}{c}\text { Atwima } \\
\text { \% }\end{array}$ & $\begin{array}{c}\text { Amansie West } \\
\text { \% }\end{array}$ \\
\hline Once per week & 1.1 & 0.0 \\
Once per fortnight & 18.1 & 0.6 \\
Once per month & 8.5 & 6.6 \\
Not met one in the last year & 72.3 & 89.5 \\
Total & 100 & $96.7^{*}$ \\
$\mathrm{~N}$ & 94 & 181 \\
\hline
\end{tabular}

Source: Survey data. * Not equal to 100 because of non-response 
ship between farmers' district of residence and access to research-based information is accepted. The difference in access to research-based information might lie with the category not met one in the last year. Comparing the actual and expected (this is under the null hypothesis of no difference between the two districts) counts (of that category) of the two districts, it can be said that Amansie farmers are more likely not to meet an extension officer compared to Atwima farmers (151 farmers were expected not to have met an extension agent, 162 actually did not; compared to Atwima where the actual count was 68 with expected count of 78 . These differences might also reflect the relative difficulty in moving into and around Amansie West (poorer road network, fewer cars and lorries) compared to Atwima. An extension officer (Amansie West) said this when queried about farmers' complaints of inactivity on the part of extension agents: 'It is true that our agents have not been working as they should. But look at the state of roads here, with no motorbikes and very few buses and lorries, it is difficult for any agent to move about'.

\section{CONCLUSION}

This study has revealed the poor state of extension support to Ghanaian cocoa farmers, a situation that needs to be rectified if farmers are to benefit from the available technological and allied information to improve their productivity. Theoretical expectations (Tripp et al., 2004; Bembridge, 1993; van den Ban and Hawkins, 1996) are that farmers of higher socio-economic status have closer affinity to extension agents and therefore tend to receive the information they need. Consistent with these expectations, class of farmer, which is the main typological classification of cocoa farmers, showed a significant association with access to research-based information. The other factors or variables (apart from district of residence) were not significant and this might be due to the fact that the level of extension support to farmers is low such that differences in access due to these characteristics are masked.
Reliance on one-on-one exchanges between farmers and extension agents has proven difficult in meeting the information needs of farmers. There is therefore the need for extension agencies to use other information dissemination channels including the radio to enhance interactive communication with farmers. The radio could enhance interactive communication because of improvements in telecommunications in Ghana which allow audiences to react to radio broadcasts by way of phone-ins.

\section{ACKNOWLEDGEMENTS}

The author is grateful to the editorial board of CRIG for reviewing the paper and to the Executive Director of CRIG for the permission to publish it. The technical assistance of Dickson Agyapong and Osei Sarkodie is acknowledged.

\section{REFERENCES}

Abenyaga, O and Gockowski, J. (2001). Labour practices in the cocoa sector of Ghana with a special focus on the role of children: findings from a survey of cocoa producing households. Ibadan: STCP / IITA Monograph.

Arhin, K. (1985). The expansion of cocoa production in Ghana: the working conditions of migrant cocoa farmers in the Central and Western regions. Legon: Institute of Statistical, Social and Economic Research, University of Ghana.

Asante, E.G. (1998). An empirical analysis of the impact of farmer managerial capacity on technology adoption in a developing market economy: a case study of cocoa farming in Ghana. Report to Winrock International, Harare. Tafo: Cocoa Research Institute of Ghana.

Baah, F. (2006). Cocoa cultivation in Ghana: an analysis of farmers' information and knowledge systems and attitudes. Ph.D thesis, Institute of International Development and Applied Economics, University of Reading, UK.

16 Journal of Science and Technology, Vol. 28, No. 3, Dec., 2008 
Barnard, C.S. (1979). Introduction. In: Blackie, J.A. and J.B. Dent (eds). Information systems for agriculture, chapter 1. London: Applied Science Publishers.

Bembridge, T.J. (1993). Farmer characteristics and contact with information sources in a Venda village; implications for extension. South African Journal of Agricultural Extension, Vol 3: 19-28.

Boahene, K. (1995). Innovation adoption as a socio-economic process: the case of the Ghanaian cocoa industry. Amsterdam: Thesis Publishers.

Boahene, K., Snijders, T.A.B. and Folmer, H (1999). An integrated socio-economic analysis of innovation adoption: the case of hybrid cocoa in Ghana. Journal of Policy Modelling,21 (2): 167-184.

Casley, D.J. and Kumar, K. (1988). The collection, analysis and use of monitoring and evaluation data. Washington D.C.: The World Bank/John Hopkins University Press.

COCOBOD (1995). Report on causes of recent decline in cocoa production and measures to revamp the sector. Accra; Ghana Cocoa Board.

De Vaus, D. (2002). Surveys in social research ( $5^{\text {th }}$ edition). London: Routledge.

Donkor, M.A., Jones, A.P and Henderson, C.P. (1991). Survey to quantify adoption of cocoa production technologies in Ghana, FSU research report 3, Tafo: Cocoa Research Institute of Ghana.

FAO/World Bank (1986). Draft report on Third cocoa project for Ghana. Ghana agricultural sector review. World Bank report No. 5366 -GH, Washington D.C.: The World Bank.

Hornik, R.C. (1988). Development communication: information, agriculture and nutrition in the third world. London and New York; Longman.

ICCO (2007). Quarterly Bulletin of Cocoa Statistics, Vol. XXXIII, International Cocoa Organisation, London.
ISNAR (1991). Review of Ghana agricultural research system, vol. II, annexes. The Hague: International Service for National Agricultural Research (ISNAR).

Marsh, C. (1982). The survey method: the contribution of surveys to sociological explanation. London: George Allen and Unwin.

Matthew-Njoku, E.C. (2003). Farmers personal and farm enterprise characteristics and their adoption of improved cassava production in Imo State, Nigeria. Journal of Agriculture and Social Research, 3 (1): 90-104.

Matthews-Njoku, E.C. and Asiabaka, C.C. (2003). Relationship between farmers' knowledge about improved cassava production technologies and adoption. Journal of Agriculture and Social Research, 3 (2): 12-17.

Myren, D. (1964). The role of information in farm decisions under conditions of high risk and uncertainty. First inter-American research symposium on the role of communications in agricultural development, Mexico City.

Opare, K.D. (1977). The role of agricultural extension in the adoption of innovations by cocoa growers in Ghana. Rural Sociology, 42 (1): 72-82.

Rogers, E.M. (1995). Diffusion of Innovations. New York: Free Press, fourth edition.

Röling, N. and Engel, P.G.H. (1991). The development of the concept of agricultural knowledge and information systems (AKIS): implications for extension. In: Rivera, W.M and Gustafson, D.J (eds), agricultural extension: worldwide institutional evolutions and forces for change, pp. 125137. Amsterdam: Elsevier Publishers.

Smyth, R. (2004). Exploring the usefulness of a conceptual framework as a research tool: a researcher's reflections. Issues in educational research, 14, Online: http;// education.curtin.edu.au/iier/iier14/smyth. html [20/02/06]. 
Tripp, R., Wijeratne, M and Piyadasa, H. (2004). After school: the outcome of farmer field schools in southern Sri Lanka. Online: http://www.odi.org.uk/rpeg/research/ natural_resources/LEITpapers/Srilanka.pdf [04/09/06]
Van den Ban, A.W. and Hawkins, H.S. (1996). Agricultural Extension ( $7^{\text {th }}$ edition). Oxford: Blackwell science.

18 Journal of Science and Technology, Vol. 28, No. 3, Dec., 2008 